\title{
Evaluation of Two Formulations of Chlorantraniliprole as Maize Protectants for the Management of Prostephanus truncatus (Horn) (Coleoptera: Bostrychidae)
}

\author{
Maria C. Boukouvala and Nickolas G. Kavallieratos * $\mathbb{D}$ \\ Laboratory of Agricultural Zoology and Entomology, Department of Crop Science, \\ Agricultural University of Athens, 75 Iera Odos Str., 11855 Athens, Attica, Greece; mbouk@aua.gr \\ * Correspondence: nick_kaval@aua.gr; Tel.: +30-210-529-4569
}

check for

updates

Citation: Boukouvala, M.C.; Kavallieratos, N.G. Evaluation of Two Formulations of Chlorantraniliprole as Maize Protectants for the Management of Prostephanus truncatus (Horn) (Coleoptera: Bostrychidae). Insects 2021, 12, 194 https://doi.org/10.3390/ insects12030194

Academic Editor: David Schlipalius

Received: 3 February 2021

Accepted: 18 February 2021

Published: 25 February 2021

Publisher's Note: MDPI stays neutral with regard to jurisdictional claims in published maps and institutional affiliations.

Copyright: (c) 2021 by the authors. Licensee MDPI, Basel, Switzerland. This article is an open access article distributed under the terms and conditions of the Creative Commons Attribution (CC BY) license (https:/ / creativecommons.org/licenses/by/ $4.0 /)$.
Simple Summary: Prostephanus truncatus (Horn) (Coleoptera: Bostrychidae) is a major insect pest of stored maize and dried tubers of cassava, but also a wood-boring species. In the current study, we evaluated two chlorantraniliprole formulations, WG (wettable granule) and SC (suspension concentrate), as maize protectants against $P$. truncatus adults at 20,25 and $30{ }^{\circ} \mathrm{C}$. Both formulations performed similarly. The highest mortality was noted in chlorantraniliprole WG, at $10 \mathrm{ppm}$ and $30{ }^{\circ} \mathrm{C}(98.9 \%)$, followed by chlorantraniliprole SC $(96.1 \%)$, at the same dose and temperature. WG formulation was more effective at $10 \mathrm{ppm}$ and $25^{\circ} \mathrm{C}(92.8 \%)$ than SC formulation (89.4\%). No progeny production was noted on maize treated the WG formulation at 20 and $30{ }^{\circ} \mathrm{C}$. The SC formulation caused complete offspring suppression at $10 \mathrm{ppm}$ at all three tested temperatures. The results indicate that chlorantraniliprole is an effective compound with a high insecticidal activity against $T$. truncatus that depends on temperature, dose and exposure.

Abstract: The larger grain borer, Prostephanus truncatus (Horn) (Coleoptera: Bostrychidae) is one of the most destructive insect pests of stored maize and dried tubers of cassava, and a wood-boring species. In the present study, we examined two chlorantraniliprole formulations, WG (wettable granule) with $350 \mathrm{~g} / \mathrm{kg}$ active ingredient (a.i.) and SC (suspension concentrate) with $200 \mathrm{~g} / \mathrm{L}$ a.i., as maize protectants against $P$. truncatus adults. Chlorantraniliprole formulations were applied as solutions at $0.01,0.1,1$ and $10 \mathrm{ppm}$, and tested at 20,25 and $30^{\circ} \mathrm{C}$. Both formulations performed similarly. After 7 days of exposure, the overall mortality provided by both formulations was very low $(<17 \%)$. Seven days later, mortality was remarkably increased on maize treated with 1 and $10 \mathrm{ppm}$ at 25 and $30{ }^{\circ} \mathrm{C}$ for both formulations. The highest mortality was noted in chlorantraniliprole WG, at $10 \mathrm{ppm}$ and $30{ }^{\circ} \mathrm{C}(98.9 \%)$, followed by chlorantraniliprole SC (96.1\%), at the same dose and temperature. WG formulation was more effective at $10 \mathrm{ppm}$ and $25^{\circ} \mathrm{C}(92.8 \%)$ than SC formulation (89.4\%). No progeny production was noted on maize treated with the WG formulation at 20 and $30^{\circ} \mathrm{C}$. The $\mathrm{SC}$ formulation caused complete offspring suppression at $10 \mathrm{ppm}$ at all three tested temperatures. The results of the present work indicate that chlorantraniliprole is an effective compound with a high insecticidal activity against T. truncatus on stored maize that depends on temperature, dose and exposure interval. The fact that chlorantraniliprole is a broad-spectrum insecticide, exhibiting low toxicity to mammals and beneficial arthropods, could be a valuable management tool in storage facilities.

Keywords: larger grain borer; anthranilic diamide; formulations; stored maize; grain protectants

\section{Introduction}

The novel insecticide, chlorantraniliprole belongs to the chemical class of anthranilic diamides [1,2] that exhibits low toxicity to mammals [3] or to beneficial arthropods [4,5] and high toxicity to insect targets [6]. This insecticide has a unique mode of action, i.e., it activates the ryanodine receptor in insects' muscles causing the release of cellular calcium that provokes termination of feeding, lethargy, paralysis of muscles and eventually leads to 
death $[2,3,7]$. Its insecticidal activity has been proved very effective against pests belonging to Coleoptera [8,9], Diptera [10], Hemiptera [11], Isoptera [12], Lepidoptera [13-15] and Thysanoptera [16]. However, an extensive examination in the international bibliography revealed few data about the insecticidal activity of chlorantraniliprole against insect pests of stored products. For example, Saglam et al. [17] examined this compound as surface treatment on concrete, against different life stages (i.e., egg, young and old larvae, pupae and adults) of the confused flour beetle, Tribolium confusum Jacquelin du Val (Coleoptera: Tenebrionidae). Kavallieratos et al. [18] reported that two chlorantraniliprole formulations were effective against the Mediterranean flour moth, Ephestia kuehniella Zeller (Lepidoptera: Pyralidae), the psocid Liposcelis bostrychophila Badonnel (Psocoptera: Liposcelididae), the lesser grain borer, Rhyzopertha dominica (F.) (Coleoptera: Bostrychidae), the rice weevil, Sitophilus oryzae (L.) (Coleoptera: Curculionidae) and T. confusum on six different commodities (i.e., barley, maize, oats, peeled rice, whole rice and wheat).

The larger grain borer, Prostephanus truncatus (Horn) (Coleoptera: Bostrychidae) is one of the most destructive insect pests of stored maize and dried tubers of cassava [19-23]. Prostephanus truncatus is also a dangerous wood-boring species to several forest plants [23-25]. It is native to Central and South America [26] from where it was accidentally introduced to Africa, and first recorded in Tanzania in the late 1970s [27-29]. Afterwards, P. truncatus spread in many African countries has been very rapid [23,30-32] as it has been favored by the fact it was able to remain in forest habitats for short periods [33]. This dangerous species exhibits high potential to become further spread in other continents [23]. Prostephanus truncatus may survive marginally on triticale, rice and whole oat flakes, and on different types of flour, i.e., whole barley flour, white soft wheat flour, whole soft wheat flour, white hard wheat flour and whole rye flour, indicating its undetected dispersion in the warehouses [34]. On the other hand, maize infestation by P. truncatus can occur before harvest [35], when its presence is not easy to detected, and therefore it can be easily introduced in the storage facilities with the infested seeds [35,36].

Prostephanus truncatus has developed resistance to several insecticidal compounds used for the protection of cereals during storage, such as organophosphorus compounds and pyrethroids $[23,37]$. It is also tolerant to various diatomaceous earths (DEs) used as maize protectants $[38,39]$. Therefore, it is vital to examine new and environmentally friendly substances, with a broad-spectrum insecticidal activity for the control of this species, taking into account that abiotic conditions are crucial for its development and damage potential [40]. Thus, the objective of the present study is to evaluate the insecticidal efficacy of two commercial formulations of chlorantraniliprole on stored maize, against $P$. truncatus under different temperatures: 20,25 and $30^{\circ} \mathrm{C}$. Progeny production of $P$. truncatus has been estimated as well.

\section{Materials and Methods}

\subsection{Insect, Commodity and Insecticidal Formulations}

Prostephanus truncatus was cultured on whole maize seeds at $30{ }^{\circ} \mathrm{C}, 65 \%$ relative humidity and continuous darkness. The adults used in the experiments were unsexed and $<2$ weeks old. All individuals were taken from a colony maintained since 2014 in the Laboratory of Agricultural Zoology and Entomology, Agricultural University of Athens. Clean and free of infestation and pesticides maize, Zea mays L. (var. Dias) was used in the experiments. The moisture content of maize was $11.6 \%$ as determined by a moisture meter (mini GAC plus, Dickey-John Europe S.A.S., Colombes, France). The following two chlorantraniliprole formulations were used for the experiments: Altacor ${ }^{\circledR}$ WG (wettable granule) with $350 \mathrm{~g} / \mathrm{kg}$ active ingredient (a.i.) and Coragen ${ }^{\circledR} \mathrm{SC}$ (suspension concentrate) with $200 \mathrm{~g} / \mathrm{L}$ a.i., both provided by Dupont (Halandri, Greece).

\subsection{Bioassays}

The chlorantraniliprole formulations were applied as solutions at $0.01,0.1,1$ and $10 \mathrm{ppm}$ a.i. based on Kavallieratos et al. [18]. One $\mathrm{kg}$ lots of maize were laid out on different 
trays and sprayed with $3 \mathrm{~mL}$ of an aqueous solution that contained the appropriate volume of WG or SC. For that purpose, an AG-4 airbrush (Mecafer S.A., Valence, France) was used. The airbrush was cleaned with acetone after the application of each dose of each formulation. The treated lots were then put into $5 \mathrm{~L}$ glass jars and were manually shaken for $10 \mathrm{~min}$ in order to achieve equal distribution of the insecticide in the entire maize mass [18]. Two additional lots of $1 \mathrm{~kg}$ maize each were treated with $3 \mathrm{~mL}$ of distilled water, using a different AG-4 airbrush, and served as controls. Three samples of $20 \mathrm{~g}$ each were taken from each treated or untreated lot and put into small glass vials $(7.5 \mathrm{~cm}$ diameter by $12.5 \mathrm{~cm}$ height) with a different scoop that was inside each jar. Samples were weighed with a Precisa XB3200D compact balance (Alpha Analytical Instruments, Gerakas, Greece) using a different thin layer for each weighing. The lids of the vials had a $1.5 \mathrm{~cm}$ diameter hole in the middle, which was covered by gauze to allow sufficient aeration inside the vial. Then, 20 adults of $P$. truncatus were separately put inside each vial. The upper internal part of each vial was coated by polytetrafluoroethylene $(60 \mathrm{wt} \%$ dispersion in water) (Northern Products Inc., Woonsocket, RI, USA) to prevent insect escape. Subsequently, all vials were placed inside an incubator set at $20^{\circ} \mathrm{C}$ and $65 \%$ relative humidity. After 7 and 14 days of exposure, mortality was determined under an Olympus stereomicroscope (Olympus SZX9; Bacacos S.A., Athens, Greece) by prodding each insect gently with a brush (Cotman 111 No. 000, Winsor and Newton, London, UK) to detect any movement. Different brushes were used per dose/formulation and controls. At the 14 day evaluation of mortality, all alive or dead parental individuals were discarded and the vials were placed again inside the incubator for an additional period of 45 days. Then, the vials were opened and the progeny production (dead or alive) was estimated as described. The experiment was replicated three times by preparing a new series of insects, vials and maize lots each time. The entire procedure was repeated for 25 and $30{ }^{\circ} \mathrm{C}$ at $65 \%$ relative humidity as aforementioned. Each bioassay for each temperature was prepared within a three-day period.

\subsection{Data Analysis}

Mortality was very low in the control vials $(<5 \%)$, therefore any correction was not necessary for the mortality counts. Prior to analysis, the mortality data were arcsine square root-transformed to normalize variance [41,42]. Statistical analysis was carried out according to the repeated-measures model [43]. The repeated factor was the exposure interval and mortality was the response variable. Formulation, temperature and dose were the main effects. The associated interactions of the main effects were incorporated in the analysis. Progeny production counts were subjected to a three-way ANOVA. Formulation, temperature and dose were the main effects. Number of progeny was the response variable. The associated interactions of the main effects and progeny production in the control vials were considered into the analysis. Means were separated by the Tukey-Kramer honestly significant difference (HSD) test at 0.05 level of significance [44]. JMP 14 software [45] was used to perform all analyses.

\section{Results}

\subsection{Mortality of P. truncatus Adults}

Between exposure intervals, all main effects and the associated interactions formulation $\times$ dose and temperature $\times$ dose were significant (Table 1). Within exposure intervals, all main effects and the associated interaction exposure $\times$ temperature $\times$ dose were significant.

After 7 days of exposure, the overall mortality provided by both formulations was very low. At $30^{\circ} \mathrm{C}$, mortality was slightly higher than at 25 or $20^{\circ} \mathrm{C}$, reaching 14.4 and $16.7 \%$ for chlorantraniliprole WG and SC, respectively (Tables 2 and 3). Seven days later, mortality was remarkably increased on maize treated with 1 and $10 \mathrm{ppm}$ at 25 and $30^{\circ} \mathrm{C}$ for both formulations. At $20^{\circ} \mathrm{C}$, moderate mortality was recorded at the same doses, not exceeding 40.0 and $45.6 \%$ for chlorantraniliprole WG (Table 2), and 36.7 and $46.1 \%$ for chlorantraniliprole SC (Table 3). The highest mortality was noted on maize treated with chlorantraniliprole WG at $10 \mathrm{ppm}$ and $30^{\circ} \mathrm{C}(98.9 \%)$, followed by chlorantraniliprole SC 
$(96.1 \%)$, at the same dose and temperature. Furthermore, WG formulation was also more effective $(92.8 \%)$ than $\mathrm{SC}$ formulation $(89.4 \%)$ at $10 \mathrm{ppm}$ and $25^{\circ} \mathrm{C}$.

Table 1. Multivariate Analysis of Variance (MANOVA) parameters for main effects and associated interactions for mortality levels of Prostephanus truncatus adults between and within exposure intervals (total degrees of freedom, $\mathrm{DF}=192)$.

\begin{tabular}{cccc}
\hline Between Exposure Intervals & & & \\
\hline Source & DF & $F$ & $p$ \\
Formulation & 1 & 6.4 & 0.01 \\
Temperature & 2 & 131.1 & $<0.01$ \\
Dose & 3 & 232.3 & $<0.01$ \\
Formulation $\times$ temperature & 2 & 1.6 & 0.21 \\
Formulation $\times$ dose & 3 & 5.3 & 0.01 \\
Temperature $\times$ dose & 6 & 11.4 & $<0.01$ \\
Formulation $\times$ temperature $\times$ dose & 6 & 1.4 & 0.21 \\
\hline Within Exposure Intervals & & & \\
Source & DF & $F$ & $p$ \\
Exposure $\times$ formulation & 1 & 9.8 & 0.01 \\
Exposure $\times$ temperature & 2 & 43.7 & $<0.01$ \\
Exposure $\times$ dose & 3 & 187.7 & $<.01$ \\
\hline Exposure $\times$ formulation $\times$ temperature & 2 & 1.6 & 0.21 \\
Exposure $\times$ formulation $\times$ dose & 3 & 2.1 & 0.10 \\
Exposure $\times$ temperature $\times$ dose & 6 & 7.4 & $<0.01$ \\
Exposure $\times$ formulation $\times$ temperature $\times$ dose & 6 & 0.5 & 0.91 \\
\hline
\end{tabular}

Table 2. Mean mortality (\% \pm SE) of Prostephanus truncatus adults after 7 and 14 days on maize treated with the WG formulation of chlorantraniliprole, at four doses $(0.01,0.1,1$ and $10 \mathrm{ppm})$ under three temperatures $\left(20,25\right.$ and $\left.30^{\circ} \mathrm{C}\right)$. Within each column, means followed by the same lowercase letter are not significantly different (in all cases DF $=3,35$, Tukey-Kramer HSD test at 0.05). Within each row, means followed by the same uppercase letter are not significantly different (in all cases $\mathrm{DF}=2,26$, Tukey-Kramer HSD test at 0.05 ). Where no letters exist, no significant differences were recorded.

\begin{tabular}{|c|c|c|c|c|c|}
\hline \multirow[b]{2}{*}{ Temperature } & \multicolumn{5}{|c|}{ Exposure: 7 Days } \\
\hline & $20{ }^{\circ} \mathrm{C}$ & $25^{\circ} \mathrm{C}$ & $30^{\circ} \mathrm{C}$ & & \\
\hline Dose (ppm) & & & & $F$ & $p$ \\
\hline 0.01 & $1.1 \pm 0.7 \mathrm{AB}$ & $0.0 \pm 0.0 \mathrm{Bb}$ & $6.1 \pm 2.5 \mathrm{Ab}$ & 5.3 & 0.01 \\
\hline 0.1 & $2.2 \pm 0.9 \mathrm{~B}$ & $4.4 \pm 1.6 \mathrm{Bab}$ & $10.6 \pm 2.7 \mathrm{Aab}$ & 6.6 & 0.01 \\
\hline 1 & $2.7 \pm 1.2 \mathrm{~B}$ & $6.1 \pm 2.5 \mathrm{ABab}$ & $11.7 \pm 2.2 \mathrm{Aab}$ & 5.5 & 0.01 \\
\hline 10 & $3.9 \pm 1.4 \mathrm{~B}$ & $9.4 \pm 2.9 \mathrm{ABa}$ & $14.4 \pm 1.6 \mathrm{Aa}$ & 6.4 & 0.01 \\
\hline$F$ & 0.9 & 4.7 & 4.1 & & \\
\hline \multirow[t]{3}{*}{$p$} & 0.45 & 0.01 & 0.01 & & \\
\hline & \multicolumn{5}{|c|}{ Exposure: 14 Days } \\
\hline & & & & $F$ & $p$ \\
\hline 0.01 & $7.2 \pm 1.7 \mathrm{~b}$ & $11.1 \pm 4.5 \mathrm{~d}$ & $25.0 \pm 9.5 b$ & 2.6 & 0.10 \\
\hline 0.1 & $12.8 \pm 1.2 \mathrm{Bb}$ & $34.4 \pm 5.2 \mathrm{Ac}$ & $49.4 \pm 7.4 \mathrm{Ab}$ & 13.4 & 0.01 \\
\hline 1 & $40.0 \pm 3.6 \mathrm{Ca}$ & $78.9 \pm 3.8 \mathrm{Bb}$ & $92.2 \pm 2.1 \mathrm{Aa}$ & 51.9 & $<0.01$ \\
\hline 10 & $45.6 \pm 2.9 \mathrm{Ba}$ & $92.8 \pm 2.8 \mathrm{Aa}$ & $98.9 \pm 2.3 \mathrm{Aa}$ & 64.7 & $<0.01$ \\
\hline$F$ & 41.0 & 59.1 & 33.0 & & \\
\hline$p$ & $<0.01$ & $<0.01$ & $<0.01$ & & \\
\hline
\end{tabular}

\subsection{Progeny Production of P. truncatus Adults}

The main effects, temperature and dose, and the associated interaction temperature $\times$ dose, were significant (Table 4). 
Concerning the controls for both formulations, the highest progeny production was recorded at $30^{\circ} \mathrm{C}$, followed by $25^{\circ} \mathrm{C}$ and $20^{\circ} \mathrm{C}$ (Tables 5 and 6). The increase of dose reduced the progeny emergence for both formulations. The highest progeny production was noted at 0.01 and $0.1 \mathrm{ppm}$ for both formulations. No progeny production was noted at $20^{\circ} \mathrm{C}$ on maize treated with $1 \mathrm{ppm}$ of chlorantraniliprole WG. The WG formulation suppressed completely the offspring emergence on maize treated with $10 \mathrm{ppm}$ at 20 and $30^{\circ} \mathrm{C}$, while 0.2 adults per vial were found at $25^{\circ} \mathrm{C}$ (Table 5). Regarding SC formulation, complete offspring suppression was achieved only at $10 \mathrm{ppm}$ and all three tested temperatures (Table 6).

Table 3. Mean mortality ( $\% \pm \mathrm{SE}$ ) of Prostephanus truncatus adults after 7 and 14 days on maize treated with the $\mathrm{SC}$ formulation of chlorantraniliprole, at four doses $(0.01,0.1,1$ and $10 \mathrm{ppm})$ under three temperatures $\left(20,25\right.$ and $\left.30^{\circ} \mathrm{C}\right)$. Within each column, means followed by the same lowercase letter are not significantly different (in all cases DF $=3,35$, Tukey-Kramer HSD test at 0.05). Within each row, means followed by the same uppercase letter are not significantly different (in all cases DF $=2$, 26, Tukey-Kramer HSD test at 0.05). Where no letters exist, no significant differences were recorded.

\begin{tabular}{cccccc}
\hline \multicolumn{5}{c}{ Exposure: $\mathbf{7}$ Days } \\
\hline Temperature & $\mathbf{2 0}{ }^{\circ} \mathbf{C}$ & $\mathbf{2 5}{ }^{\circ} \mathbf{C}$ & $\mathbf{3 0}{ }^{\circ} \mathbf{C}$ & & \\
\hline Dose $(\mathrm{ppm})$ & & & & \\
0.01 & $1.1 \pm 0.7$ & $1.7 \pm 0.8 \mathrm{~b}$ & $3.9 \pm 1.1 \mathrm{~b}$ & 2.4 & 0.11 \\
0.1 & $2.2 \pm 0.9$ & $2.2 \pm 0.9 \mathrm{ab}$ & $5.0 \pm 1.2 \mathrm{~b}$ & 2.0 & 0.16 \\
1 & $2.8 \pm 0.9 \mathrm{~B}$ & $6.1 \pm 1.6 \mathrm{Bab}$ & $15.6 \pm 2.8 \mathrm{Aa}$ & 10.5 & 0.01 \\
10 & $3.3 \pm 1.2 \mathrm{~B}$ & $7.2 \pm 1.5 \mathrm{ABa}$ & $16.7 \pm 3.2 \mathrm{Aa}$ & 9.6 & 0.01 \\
$F$ & 1.0 & 4.6 & 9.0 & & \\
$p$ & 0.43 & 0.01 & 0.01 & & \\
\hline \multicolumn{7}{c}{ Exposure: $\mathbf{1 4} \mathrm{Days}$} & & \\
\hline 01 & $7.8 \pm 1.2 \mathrm{~b}$ & $8.9 \pm 1.1 \mathrm{~b}$ & $12.8 \pm 2.5 \mathrm{~b}$ & 1.5 & 0.25 \\
0.1 & $10.0 \pm 1.4 \mathrm{~b}$ & $11.1 \pm 2.2 \mathrm{~b}$ & $17.2 \pm 2.2 \mathrm{~b}$ & 2.8 & 0.08 \\
1 & $36.7 \pm 4.2 \mathrm{Ba}$ & $76.7 \pm 5.0 \mathrm{Aa}$ & $90.6 \pm 1.6 \mathrm{Aa}$ & 35.5 & $<0.01$ \\
10 & $46.1 \pm 5.3 \mathrm{Ba}$ & $89.4 \pm 3.5 \mathrm{Aa}$ & $96.1 \pm 1.4 \mathrm{Aa}$ & 39.9 & $<0.01$ \\
$F$ & 32.5 & 78.9 & 207.7 & & \\
$p$ & $<0.01$ & $<0.01$ & $<0.01$ & & \\
\hline
\end{tabular}

Table 4. ANOVA parameters for progeny production of Prostephanus truncatus (total DF = 269).

\begin{tabular}{cccc}
\hline Source & DF & $\boldsymbol{F}$ & $p$ \\
\hline Formulation & 1 & 0.3 & 0.59 \\
Temperature & 2 & 9.0 & 0.01 \\
Dose & 4 & 89.7 & $<0.01$ \\
Formulation $\times$ temperature & 2 & 0.7 & 0.50 \\
Formulation $\times$ dose & 4 & 0.5 & 0.72 \\
Temperature $\times$ dose & 8 & 2.0 & 0.05 \\
Formulation $\times$ temperature $\times$ dose & 8 & 0.6 & 0.81 \\
\hline
\end{tabular}


Table 5. Progeny production (adults per vial \pm SE) of Prostephanus truncatus on maize treated with the WG formulation of chlorantraniliprole at five doses (0, 0.01, 0.1, 1 and 10 ppm) under three temperatures $\left(20,25\right.$ and $\left.30^{\circ} \mathrm{C}\right) 45$ days after the removal of parental adults. Within each column, means followed by the same lowercase letter are not significantly different (in all cases DF $=4,44$, Tukey-Kramer HSD test at 0.05). Within each row, means followed by the same uppercase letter are not significantly different (in all cases DF $=2,26$, Tukey-Kramer HSD test at 0.05 ). Where no letters exist, no significant differences were recorded.

\begin{tabular}{|c|c|c|c|c|c|}
\hline Temperature & $20{ }^{\circ} \mathrm{C}$ & $25{ }^{\circ} \mathrm{C}$ & $30{ }^{\circ} \mathrm{C}$ & & \\
\hline Dose (ppm) & & & & $F$ & $p$ \\
\hline 0 & $8.8 \pm 2.2 \mathrm{a}$ & $12.4 \pm 2.3 \mathrm{a}$ & $15.0 \pm 1.5 \mathrm{a}$ & 3.2 & 0.06 \\
\hline 0.01 & $7.1 \pm 2.1 \mathrm{ab}$ & $7.8 \pm 1.4 \mathrm{ab}$ & $11.2 \pm 2.6 \mathrm{a}$ & 0.5 & 0.60 \\
\hline 0.1 & $2.3 \pm 1.3 \mathrm{Bbc}$ & $4.4 \pm 1.5 \mathrm{ABbc}$ & $9.6 \pm 1.8 \mathrm{Aa}$ & 4.6 & 0.02 \\
\hline 1 & $0.0 \pm 0.0 c$ & $0.8 \pm 0.5 \mathrm{~cd}$ & $0.3 \pm 0.2 \mathrm{~b}$ & 1.2 & 0.31 \\
\hline 10 & $0.0 \pm 0.0 c$ & $0.2 \pm 0.2 \mathrm{~d}$ & $0.0 \pm 0.0 \mathrm{~b}$ & 1.0 & 0.38 \\
\hline$F$ & 10.4 & 20.9 & 25.6 & & \\
\hline$p$ & $<0.01$ & $<0.01$ & $<0.01$ & & \\
\hline
\end{tabular}

Table 6. Progeny production (adults per vial \pm SE) of Prostephanus truncatus on maize treated with the SC formulation of chlorantraniliprole at five doses $(0,0.01,0.1,1$ and $10 \mathrm{ppm})$ under three temperatures $\left(20,25\right.$ and $\left.30^{\circ} \mathrm{C}\right) 45$ days after the removal of parental adults. Within each column, means followed by the same lowercase letter are not significantly different (in all cases DF $=4,44$, Tukey-Kramer HSD test at 0.05). Within each row, means followed by the same uppercase letter are not significantly different (in all cases DF $=2,26$, Tukey-Kramer HSD test at 0.05). Where no letters exist, no significant differences were recorded. Where dashes exist, no analysis was performed.

\begin{tabular}{cccccc}
\hline Temperature & $\mathbf{2 0}{ }^{\circ} \mathbf{C}$ & $\mathbf{2 5}{ }^{\circ} \mathbf{C}$ & $30{ }^{\circ} \mathbf{C}$ & & \\
\hline Dose $(\mathrm{ppm})$ & & & & $F$ & $p$ \\
0 & $8.7 \pm 1.8 \mathrm{a}$ & $12.3 \pm 3.6 \mathrm{a}$ & $14.8 \pm 2.0 \mathrm{a}$ & 2.0 & 0.16 \\
0.01 & $5.2 \pm 1.5 \mathrm{a}$ & $6.9 \pm 2.5 \mathrm{ab}$ & $13.2 \pm 2.6 \mathrm{a}$ & 2.0 & 0.15 \\
0.1 & $3.2 \pm 0.7 \mathrm{ab}$ & $4.3 \pm 0.9 \mathrm{ab}$ & $7.8 \pm 2.0 \mathrm{a}$ & 1.0 & 0.38 \\
1 & $1.8 \pm 1.4 \mathrm{bc}$ & $2.4 \pm 1.6 \mathrm{bc}$ & $0.4 \pm 0.3 \mathrm{~b}$ & 0.6 & 0.56 \\
10 & $0.0 \pm 0.0 \mathrm{c}$ & $0.0 \pm 0.0 \mathrm{c}$ & $0.0 \pm 0.0 \mathrm{~b}$ & - & - \\
$F$ & 13.7 & 6.8 & 23.8 & & \\
$p$ & $<0.01$ & 0.01 & $<0.01$ & & \\
\hline
\end{tabular}

\section{Discussion}

Due to the high importance of $P$. truncatus and the elevated risk of its further expansion, previous research efforts have been conducted for the effective management of this species. For instance, an insecticidal formulation of spinosad, which is based on the secondary metabolites spinosyns A and D of the bacterium Saccharopolyspora spinosa Mertz and Yao (Actinomycetales: Pseudonocardiaceae) [46,47] at $0.5 \mathrm{ppm}$, was able to kill $>90 \%$ of P. truncatus adults after 7 days on maize, at 25 or $30^{\circ} \mathrm{C}$ and 55 or $75 \%$ relative humidity [48]. The pyrrole chlorfenapyr has also been proved very effective after 7 days of exposure against $P$. truncatus by causing $100 \%$ mortality on maize treated with 5 ppm at $30{ }^{\circ} \mathrm{C}$ and 55 or $75 \%$ relative humidity [49]. Similarly, 0.5 ppm of the pyrethroid deltamethrin killed $97.8 \%$ of the exposed adults, at $20^{\circ} \mathrm{C}$, while complete mortality (100\%) was recorded at 25 and $30^{\circ} \mathrm{C}$, at the same exposure interval [50]. According to our findings, both chlorantraniliprole formulations became highly toxic against $P$. truncatus at 10 ppm after 14 days of exposure at 25 and $30^{\circ} \mathrm{C}$ or at $1 \mathrm{ppm}$ at $30^{\circ} \mathrm{C}$ by killing $>90 \%$ of the exposed adults, indicating that chlorantraniliprole may cause complete mortality to this species favorably at longer exposure intervals ( $>14$ days). The enhanced diatomaceous earths (DEs), or the mixture of a DE with another active ingredient could be used as alternative compounds for the protection of stored maize against $P$. truncatus. For instance, the enhanced DE, DEA-P which is a mixture of abamectin and freshwater DE, caused almost complete mortality in all tested combinations of temperature and relative humidity at 
150 ppm after 7 days of exposure [39]. More recently, Kavallieratos et al. [51] reported the high insecticidal efficacy ( $\geq 98 \%$ ), at low doses (75 and $150 \mathrm{ppm}$ ) of DEA-P, on five different maize hybrids against $P$. truncatus after 7 days of exposure. Similar results were noted by Kavallieratos et al. [52] for S. oryzae and R. dominica. Furthermore, the combination of the DE Protect-It with spinosad or the pyrethroid deltamethrin at low doses, caused high mortalities (84.5-99.5\%) on treated maize against $P$. truncatus adults, even after 7 days of exposure [53]. Consequently, the combination of a chlorantraniliprole formulation with DEs at low doses may be more effective than the separate application of each formulation for the control of P. truncatus, even in shorter exposure intervals ( $<14$ days), an issue that merits further experimentation.

In the present study, both chlorantraniliprole formulations have been very effective and performed almost equally. This similar trend was also recorded by Kavallieratos et al. [18] for E. kuehniella larvae, L. bostrychophila adults, $R$. dominica adults, S. oryzae adults and T. confusum larvae. However, the efficacy of each formulation among species was influenced by the type of the commodity, dose and exposure. In this study, we found that temperature played an important role in their insecticidal efficacy. According to our results, the increase of temperature from 20 to $30{ }^{\circ} \mathrm{C}$ resulted in significantly higher mortalities for both formulations in the majority of the tested combinations. Temperature is a crucial factor on the effectiveness of several insecticides that are used as grain protectants against stored-product insects [54,55]. For example, Kavallieratos and Boukouvala [56] reported higher mortality levels to the khapra beetle, Trogoderma granarium Everts (Coleoptera: Dermestidae), at $35^{\circ} \mathrm{C}$ than at $30{ }^{\circ} \mathrm{C}$ on concrete treated with a mixture of acetamiprid plus d-tetramethrin plus piperonyl butoxide. In a recent study, Kavallieratos et al. [57] found that the insecticidal activity of pirimiphos-methyl against the yellow mealworm, Tenebrio molitor L. (Coleoptera: Tenebrionidae), was influenced by temperature. Concretely, the authors recorded the highest mortality rates of this species at $35^{\circ} \mathrm{C}$, followed by 30,25 and $20{ }^{\circ} \mathrm{C}$. The high effectiveness of insecticides at elevated temperatures can be explained by the fact that insects, due to their high mobility, come into contact with treated grains more often [52]. In addition, increasing the significant metabolic activities of insects when exposed to high temperatures may render them more vulnerable to toxic agents [58]. However, in the case of $P$. truncatus, there is no clear pattern about the influence of temperature on the activity of various a.i. applied on maize. Based on previous studies, chlorfenapyr, chlorpyriphosmethyl, deltamethrin, fipronil, pirimiphos-methyl, spinosad and spinetoram performed variably among 20,25 and $30{ }^{\circ} \mathrm{C}$ depending on the combinations of dose, relative humidity and exposure interval $[48-50,58,59]$. Our results indicate that in the vast majority of the tested combinations, mortality increased with the rise in temperature regardless of the chlorantraniliprole formulation. This may be happening because chlorantraniliprole belongs to a different class of insecticides than the aforementioned a.i. [60-70]. For example, pyrethroids perform differently than organophosphates in changes of temperature given that, generally, the former are negatively while the latter are positively associated with the increase of temperature $[57,71,72]$. Further studies are needed to clarify this issue.

In our study, the progeny production of P. truncatus was very low for both formulations at $10 \mathrm{ppm}$. No offspring were noted on maize treated with chlorantraniliprole SC at any temperature, while in the case of chlorantraniliprole WG, 0.2 adults per vial were found at $25^{\circ} \mathrm{C}$. This is an important finding since chlorantraniliprole suppressed both the exposed adults and progeny production regardless of temperature. The suppression of progeny production at 25 and $30^{\circ} \mathrm{C}$ is associated with the high adult mortality 14 days post-exposure. However, previous studies have shown that offspring emergence was not totally avoided even when the mortality was $100 \%$ or close to $100 \%$ on maize treated with chlorfenapyr [49] or pirimiphos-methyl and spinosad [50] or spinosad and spinetoram [58]. Most likely, females oviposited before dying, therefore some progeny were produced that eventually died [50]. The lethargy and paralysis that chlorantraniliprole induced to the exposed adults [1,2] may have not allowed them to lay eggs before their death, an issue that could further explain the absence of offspring in our experiments. This could also be the case for 
$20{ }^{\circ} \mathrm{C}$ since parental mortality ranged between 45.6 and $46.1 \%$ for both chlorantraniliprole formulations at $10 \mathrm{ppm}$. Additionally, $20^{\circ} \mathrm{C}$ does not favor the activity of P. truncatus [73], thus its development becomes slow at this temperature level.

\section{Conclusions}

To conclude, the present study indicates that chlorantraniliprole is a promising a.i. for the management of $P$. truncatus because it provides high insecticidal activity to parental adults but also suppresses progeny production on stored-maize. However, temperature, exposure and dose should be taken into account if control measures against $P$. truncatus include chlorantraniliprole, regardless of WG or SC formulations. Since chlorantraniliprole exhibits activity against several other stored-product pests [18] and presents a friendly toxicological profile [3-5], it could be considered as an additional tool for the protection of stored-grain commodities.

Author Contributions: Designed research, N.G.K.; methodology, M.C.B. and N.G.K.; investigation, M.C.B. and N.G.K.; data curation, M.C.B.; formal analysis, M.C.B. and N.G.K.; writing-original draft, M.C.B. and N.G.K.; writing-review and editing, M.C.B. and N.G.K.; supervision, N.G.K.; resources, N.G.K.; funding acquisition, N.G.K. All authors have read and agreed to the published version of the manuscript.

Funding: This research was partially funded by the 34.0401 project (Special Account for Research Funds of the Agricultural University of Athens).

Data Availability Statement: Data is contained within the article.

Conflicts of Interest: The authors declare no conflict of interest.

\section{References}

1. Lahm, G.P.; Selby, T.P.; Freudenberger, J.H.; Stevenson, T.M.; Myers, B.J.; Seburyamo, G.; Smith, B.K.; Flexner, L.; Clark, C.E.; Cordova, D. Insecticidal anthranilic diamides: A new class of potent ryanodine receptor activators. Bioorg. Med. Chem. Lett. 2005, 15, 4898-4906. [CrossRef]

2. Cordova, D.; Benner, E.; Sacher, M.; Rauh, J.; Sopa, J.; Lahm, G.; Selby, T.; Stevenson, T.; Flexner, L.; Gutteridge, S.; et al. Anthranilic diamides: A new class of insecticides with a novel mode of action, ryanodine receptor activation. Pestic. Biochem. Physiol. 2006, 84, 196-214. [CrossRef]

3. Lahm, G.P.; Stevenson, T.M.; Selby, T.P.; Freudenberger, J.H.; Cordova, D.; Flexner, L.; Bellin, C.A.; Dubas, C.M.; Smith, B.K.; Hughes, K.A.; et al. Rynaxypyr ${ }^{\mathrm{TM}}$ : A new insecticidal anthranilic diamide that acts as a potent and selective receptor activator. Bioorg. Med. Chem. Lett. 2007, 17, 6274-6279. [CrossRef] [PubMed]

4. Liu, F.; Zhang, X.; Gui, Q.Q.; Xu, Q.J. Sublethal effects of four insecticides on Anagrus nilaparvatae (Hymenoptera: Mymaridae), an important egg parasitoid of the rice planthopper Nilaparvata lugens (Homoptera: Delphacidae). Crop. Prot. 2012, 37, 13-19. [CrossRef]

5. Nawaz, M.; Cai, W.; Jing, Z.; Zhou, X.; Mabubu, J.I.; Hua, H. Toxicity and sublethal effects of chlorantraniliprole on the development and fecundity of a non-specific predator, the multicolored Asian lady beetle, Harmonia axyridis (Pallas). Chemosphere 2017, 178, 496-503. [CrossRef]

6. Lahm, G.P.; Cordova, D.; Barry, J.D. New and selective ryanodine receptor activators for insect control. Bioorg. Med. Chem. 2009, 17, 4127-4133. [CrossRef]

7. Sattelle, D.B.; Cordova, D.; Cheek, T.R. Insect ryanodine receptors: Molecular targets for novel pest control chemicals. Invertebr. Neurosci. 2008, 8, 107-119. [CrossRef] [PubMed]

8. Hummel, N.A.; Mészáros, A.; Ring, D.R.; Beuzelin, J.M.; Stout, M.J. Evaluation of seed treatment insecticides for management of the rice water weevil, Lissorhoptrus oryzophilus Kuschel (Coleoptera: Curculionidae), in commercial rice fields in Louisiana. Crop Prot. 2014, 65, 37-42. [CrossRef]

9. Plata Rueda, A.; Martínez, L.C.; Costa, N.C.R.; Zanuncio, J.C.; Fernandes, M.E.D.S.; Serrão, J.E.; Guedes, R.N.C.; Fernandes, F.L. Chlorantraniliprole-mediated effects on survival, walking abilities, and respiration in the coffee berry borer, Hypothenemus hampei. Ecotoxicol. Environ. Saf. 2019, 172, 53-58. [CrossRef] [PubMed]

10. Teixeira, L.A.F.; Gut, L.J.; Wise, J.C.; Isaacs, R. Lethal and sublethal effects of chlorantraniliprole on three species of Rhagoletis fruit flies (Diptera: Tephritidae). Pest Manag. Sci. 2008, 65, 137-143. [CrossRef] [PubMed]

11. Liu, J.L.; Yang, X.; Chen, X.; Wu, J.C. Suppression of fecundity, Nlvg gene expression and vitellin content in Nilaparvata lugens Stål (Hemiptera: Delphacidae) adult females exposed to indoxacarb and chlorantraniliprole. Pestic. Biochem. Physiol. 2012, 104, 206-211. [CrossRef] 
12. Neoh, K.B.; Hu, J.; Yeoh, B.H.; Lee, C.Y. Toxicity and horizontal transfer of chlorantraniliprole against the Asian subterranean termite Coptotermes gestroi (Wasmann): Effects of donor: Recipient ratio, exposure duration and soil type. Pest Manag. Sci. 2012, 68, 749-756. [CrossRef]

13. Munhoz, R.E.F.; Bignotto, T.S.; Pereira, N.C.; Saez, C.R.D.N.; Bespalhuk, R.; Fassina, V.A.; Pessini, G.M.; Baggio, M.P.D.; Ribeiro, L.D.F.C.; Brancalhão, R.M.C.; et al. Evaluation of the toxic effect of insecticide chlorantraniliprole on the silkworm Bombyx mori (Lepidoptera: Bombycidae). Open J. Anim. Sci. 2013, 3, 343-353. [CrossRef]

14. Liu, Y.; Gao, Y.; Liang, G.; Lu, Y. Chlorantraniliprole as a candidate pesticide used in combination with the attracticides for lepidopteran moths. PLoS ONE 2017, 12, e0180255. [CrossRef]

15. He, F.; Sun, S.; Tan, H.; Sun, X.; Qin, C.; Ji, S.; Li, X.; Zhang, J.; Jiang, X. Chlorantraniliprole against the black cutworm Agrotis ipsilon (Lepidoptera: Noctuidae): From biochemical/physiological to demographic responses. Sci. Rep. 2019, 9, 10328. [CrossRef] [PubMed]

16. Dale, A.G.; Borden, M.A. Evaluation of reduced-risk insecticides to control chilli thrips (Thysanoptera: Thripidae) and conserve natural enemies on ornamental plants. Fla. Entomol. 2018, 101, 237-243. [CrossRef]

17. Saglam, O.; Athanassiou, C.G.; Vassilakos, T.N. Comparison of spinetoram, imidacloprid, thiamethoxam and chlorantraniliprole against life stages of Tribolium confusum Jacquelin du Val (Coleoptera: Tenebrionidae) on concrete. Crop Prot. 2013, 53, 85-95. [CrossRef]

18. Kavallieratos, N.G.; Athanassiou, C.G.; Boukouvala, M.C. Insecticidal effect of chlorantraniliprole against major stored-product insect pests in different grain commodities under laboratory tests. Pest Manag. Sci. 2013, 69, 1141-1154. [CrossRef]

19. Schäfer, K.; Gorgen, G.; Borgemeister, C. An illustrated identification key to four different species of adult Dinoderus (Coleoptera: Bostrichidae), commonly attacking dried cassava chips in West Africa. J. Stored Prod. Res. 2000, 36, 245-252. [CrossRef]

20. Gnonlonfin, G.; Hell, K.; Siame, A.B.; Fandohan, P. Infestation and population dynamics of insects on stored cassava and yams chips in Benin, West Africa. J. Econ. Entomol. 2008, 101, 1967-1973. [CrossRef] [PubMed]

21. Giliomee, J.H. Recent establishment of many alien Insects in South Africa-A cause for concern. Afr. Entomol. 2011, 19, 151-155. [CrossRef]

22. Muatinte, B.L.; Van den Berg, J.; Santos, L.A. Prostephanus truncatus in Africa: A review of biological trends and perspectives on future pest management strategies. Afr. Crop Sci. J. 2014, 22, 237-256.

23. Muatinte, B.L.; Kavallieratos, N.G.; Boukouvala, M.C.; García Lara, S.; Margarita López Castillo, L.M.; Mvumi, B.M. The threat of the larger grain borer, Prostephanus truncatus (Coleoptera: Bostrichidae) and practical control options for the pest. CAB Rev. 2019, 14, 1-25. [CrossRef]

24. Scholz, D.; Tchabi, A.; Borgemeister, C.; Markham, R.H.; Poehling, H.M.; Lawson, A. Host-finding behaviour of Prostephanus truncatus (Horn) (Col.: Bostricidae): Primary attraction or random attack? J. Appl. Entomol. 1997, 121, 261-269. [CrossRef]

25. Nansen, C.; Meikle, W.G.; Tigar, B.; Harding, S.; Tchabi, A. Nonagricultural hosts of Prostephanus truncatus (Coleoptera: Bostrichidae) in a West African Forest. Ann. Entomol. Soc. Am. 2004, 97, 481-491. [CrossRef]

26. Hoppe, T. Storage insects of basic food grains in Honduras. Trop. Sci. 1986, 26, 25-28.

27. Dunstan, W.R.; Magazini, I.A. Outbreaks and new records, United Republic of Tanzania. The larger grain borer on stored products. FAO Plant Prot. Bull. 1981, 29, 80-81.

28. Hodges, R.J.; Dunstan, W.R.; Magazini, I.; Golob, P. An outbreak of Prostephanus truncatus (Horn) (Coleoptera: Bostrichidae) in East Africa. Prot. Ecol. 1983, 5, 183-194.

29. Markham, R.H.; Wright, V.F.; Rios Ibarra, R.M. A selective review of research on Prostephanus truncatus (Col: Bostrichidae) with an annotated and updated bibliography. Ceiba 1991, 32, 1-90.

30. Meikle, W.G.; Holst, N.; Scholz, D.; Markham, R.H. Simulation model of Prostephanus truncatus (Coleoptera: Bostrichidae) in rural maize stores in the Republic of Benin. Environ. Entomol. 1998, 27, 59-69. [CrossRef]

31. Addo, S.; Birkinshaw, L.A.; Hodges, R.J. Ten years after the arrival in Ghana of larger grain borer: Farmers' responses and adoption of IPM strategies. Int. J. Pest Manag. 2002, 48, 315-325. [CrossRef]

32. Farrell, G.; Schulten, G. Larger grain borer in Africa; A history of efforts to limit its impact. Integr. Pest Manag. Rev. 2002, 7, 67-84. [CrossRef]

33. Nansen, C.; Meikle, W.G.; Korie, S. Spatial analysis of Prostephanus truncatus (Bostrichidae: Coleoptera) flight activity near maize stores and in different forest types in southern Benin, West Africa. Ann. Entomol. Soc. Am. 2002, 95, 66-74. [CrossRef]

34. Athanassiou, C.G.; Kavallieratos, N.G.; Boukouvala, M.C.; Nika, E.P. Influence of commodity on the population growth of the larger grain borer, Prostephanus truncatus (Horn) (Coleoptera: Bostrychidae). J. Stored Prod. Res. 2017, 73, 129-134. [CrossRef]

35. Hill, M.G.; Borgemeister, C.; Nansen, C. Ecological studies on the larger grain borer, Prostephanus truncatus (Horn) (Coleoptera: Bostrichidae) and their implications for integrated pest management. Int. Pest Manag. Rev. 2002, 7, 201-221. [CrossRef]

36. Borgemeister, C.; Adda, C.; Djomamou, B.; Degbey, P.; Agbaka, A.; Djossou, F.; Meikle, W.G.; Markham, R.H. The effect of maize cob selection and the impact of field infestation on stored maize losses by larger grain borer (Prostephanus truncatus (Horn) Coleoptera: Bostrichidae) and associated storage pests. In Proceedings of the 6th International Working Conference on Stored-Product Protection, Canberra, Australia, 17-23 April 1994; Highley, E., Wright, E.J., Banks, H.J., Champ, B.R., Eds.; CAB International: Wallingford, UK, 1994; pp. 906-909.

37. Golob, P. Chemical, physical and cultural control of Prostephanus truncatus. Integr. Pest Manag. Rev. 2002, 7, 245-277. [CrossRef] 
38. Athanassiou, C.G.; Korunic, Z.; Kavallieratos, N.G.; Peteinatos, C.G.; Boukouvala, M.C.; Mikeli, N.H. New trends in the use of diatomaceous earth against stored-grain insects. In Proceedings of the 9th International Working Conference on Stored-Product Protection, Campinas, Brazil, 15-18 October 2006; Lorini, I., Bacaltchuk, B., Beckel, H., Deckers, D., Sundfeld, E., dos Santos, J.P., Biagi, J.D., Celaro, J.C., Faroni, L.R.D., de Bortolini, L.O.F., et al., Eds.; ABRAPOS: Passo Fundo, Brazil, 2006 ; pp. 730-740.

39. Athanassiou, C.G.; Kavallieratos, N.G.; Peteinatos, G.G.; Petrou, S.E.; Boukouvala, M.C.; Tomanović, Ž. Influence of temperature and humidity on insecticidal effect of three diatomaceous earth formulations against larger grain borer (Coleoptera: Bostrychidae). J. Econ. Entomol. 2007, 100, 599-603. [CrossRef]

40. Papanikolaou, N.E.; Kavallieratos, N.G.; Boukouvala, M.C.; Malesios, C. Do temperature, relative humidity and interspecific competition alter the population size and the damage potential of stored-product insect pests? A hierarchical multilevel modeling approach. J. Therm. Biol. 2018, 78, 415-422. [CrossRef]

41. Zar, J.H. Biostatistical Analysis; Pearson Education Limited: Essex, UK, 2014.

42. Andrić, G.; Kljajić, P.; Golić, M.P.; Trdan, S.; Bohinc, T.; Solarov, M.B. Effectiveness of spinosad and spinetoram against three Sitophilus species: Influence of wheat endosperm vitreousness. J. Stored Prod. Res. 2019, 83, 209-217. [CrossRef]

43. Sall, J.; Lehman, A.; Creighton, L. JMP start statistics. In A Guide to Statistics and Data Analysis Using JMP and JMP IN Software; Duxbury Press: Belmont, ON, Canada, 2001.

44. Sokal, R.R.; Rohlf, F.J. Biometry; Freeman \& Company: New York, NY, USA, 1995.

45. SAS Institute Inc. Using JMP 14; SAS Institute Inc.: Cary, NC, USA, 2018.

46. Thompson, G.D.; Michel, K.H.; Yao, R.C.; Mynderse, J.S.; Mosburg, C.T.; Worden, T.V.; Chio, E.H.; Sparks, T.C.; Hutchins, S.H. The discovery of Saccharopolyspora spinosa and a new class of insect control products. Down Earth 1997, 52, 1-5.

47. Hertlein, M.B.; Thompson, G.D.; Subramanyam, B.; Athanassiou, C.G. Spinosad: A new natural product for stored grain protection. J. Stored Prod. Res. 2011, 47, 131-146. [CrossRef]

48. Athanassiou, C.G.; Kavallieratos, N.G.; Yiatilis, A.E.; Vayias, B.J.; Mavrotas, C.S.; Tomanović, Ž. Influence of temperature and humidity on the efficacy of spinosad against four stored-grain beetle species. J. Insect Sci. 2008, 8, 1-9. [CrossRef]

49. Kavallieratos, N.G.; Athanassiou, C.G.; Hatzikonstantinou, A.N.; Kavallieratou, H.N. Abiotic and biotic factors affect efficacy of chlorfenapyr for control of stored-product insect pests. J. Food Prot. 2011, 74, 1288-1299. [CrossRef] [PubMed]

50. Pozidi Metaxa, E.; Athanassiou, C.G. Comparison of spinosad with three traditional grain protectants against Prostephanus truncatus (Horn) and Ephestia kuehniella (Zeller) at different temperatures. J. Pest Sci. 2012, 86, 203-210. [CrossRef]

51. Kavallieratos, N.G.; Athanassiou, C.G.; Peteinatos, G.G.; Boukouvala, M.C.; Benelli, G. Insecticidal effect and impact of fitness of three diatomaceous earths on different maize hybrids for the eco-friendly control of the invasive stored-product pest Prostephanus truncatus (Horn). Environ. Sci. Pollut. Res. 2018, 25, 10407-10417. [CrossRef]

52. Kavallieratos, N.G.; Athanassiou, C.G.; Korunic, Z.; Mikeli, N.H. Evaluation of three novel diatomaceous earths against three stored-grain beetle species on wheat and maize. Crop. Prot. 2015, 75, 132-138. [CrossRef]

53. Machekano, H.; Mvumi, B.M.; Chinwada, P.; Richardson Kageler, S.J.; Rwafa, R. Efficacy of diatomaceous earths and their low-dose combinations with spinosad or deltamethrin against three beetle pests of stored-maize. J. Stored Prod. Res. 2017, 72, 128-137. [CrossRef]

54. Boukouvala, M.C.; Kavallieratos, N.G.; Athanassiou, C.G.; Hadjiarapoglou, L.P. Biological activity of two new pyrrole derivatives against stored-product species: Influence of temperature and relative humidity. Bull. Entomol. Res. 2016, 106, 446-456. [CrossRef] [PubMed]

55. Boukouvala, M.C.; Kavallieratos, N.G.; Athanassiou, C.G.; Losic, D.; Hadjiarapoglou, L.P.; Elemes, Y. Laboratory evaluation of five novel pyrrole derivatives as grain protectants against Tribolium confusum and Ephestia kuehniella larvae. J. Pest Sci. 2017, 90, 569-585. [CrossRef]

56. Kavallieratos, N.G.; Boukouvala, M.C. Efficacy of d-tetramethrin and acetamiprid for control of Trogoderma granarium Everts (Coleoptera: Dermestidae) adults and larvae on concrete. J. Stored Prod. Res. 2019, 80, 79-84. [CrossRef]

57. Kavallieratos, N.G.; Papanikolaou, N.E.; Kazani, A.N.; Boukouvala, M.C.; Malesios, C. Using multilevel models to explore the impact of abiotic and biotic conditions on the efficacy of pirimiphos-methyl against Tenebrio molitor L. Environ. Sci. Pollut. Res. 2021. [CrossRef] [PubMed]

58. Athanassiou, C.G.; Kavallieratos, N.G. Evaluation of spinetoram and spinosad for control of Prostephanus truncatus, Rhyzopertha dominica, Sitophilus oryzae and Tribolium confusum on stored grains under laboratory tests. J. Pest Sci. 2014, 87, 469-483. [CrossRef]

59. Kavallieratos, N.G.; Athanassiou, C.G.; Vayias, B.J.; Betsi, P.C.C. Insecticidal efficacy of fipronil against four stored-product insect pests: Influence of commodity, dose, exposure interval, relative humidity and temperature. Pest Manag. Sci. 2010, 66, 640-649. [CrossRef] [PubMed]

60. O'Brien, R.D. Insecticides Action and Metabolism; Academic Press Inc.: Ney York, NY, USA, 1967.

61. Donarski, W.J.; Dumas, D.P.; Heitmeyer, D.P.; Lewis, V.E.; Raushel, F.M. Structure-activity relationships in the hydrolysis of substrates by the phosphotriesterase from Pseudomonas diminuta. Biochemistry 1989, 28, 4650-4655. [CrossRef]

62. Cole, L.M.; Nicholson, R.A.; Casida, J.E. Action of phenylpyrazole insecticides at the GABA-gated chloride channel. Pestic. Biochem. Physiol. 1993, 46, 47-54. [CrossRef]

63. Hunt, D.A. 2-Arylpyrroles: A new class of insecticide. Structure, activity and mode of action. Pestic. Sci. 1996, 47, 201-202. [CrossRef] 
64. Salgado, V.L. Studies on the mode of action of spinosad: Insect symptoms and physiological correlates. Pestic. Biochem. Physiol. 1998, 60, 91-102. [CrossRef]

65. Tomlin, C.D.S. The Pesticide Manual; BCPC Publications: London, UK, 2000.

66. McLeod, P.; Diaz, F.J.; Johnson, D.T. Toxicity, persistence, and efficacy of spinosad, chlorfenapyr, and thiamethoxam on eggplant when applied against the eggplant flea beetle (Coleoptera: Chrysomelidae). J. Econ. Entomol. 2002, 95, 331-335. [CrossRef]

67. Salgado, V.L.; Sparks, T.C. The spinosyns: Chemistry, biochemistry, mode of action and resistance. In Comprehensive Insect Molecular Science; Gilbert, L.I., Iatrou, K., Gill, S., Eds.; Elsevier: Oxford, UK, 2005; Volume 6, pp. 137-173.

68. Eleršek, T.; Filipič, M. Organophoshorus pesticides-mechanisms of their toxicity. In Pesticides-The Impacts of Pesticides Exposure; Stoytcheva, M., Ed.; InTech: Rijeka, Croatia, 2011; pp. 243-260.

69. Freeborn, D.L.; McDaniel, K.L.; Moser, V.C.; Herr, D.W. Use of electroencephalography (EEG) to assess CNS changes produced by pesticides with different modes of action: Effects of permerthrin, deltamethrin, fipronil, imidacloprid, carbaryl, and triadimefon. Toxicol. Appl. Pharmacol. 2015, 282, 184-194. [CrossRef]

70. Bacci, L.; Lupi, D.; Savoldelli, S.; Rossaro, B. A review of spinosyns, a derivative of biological acting substances as a class of insecticides with a broad range of action against many insect pests. J. Entomol. Acarol. Res. 2016, 48, 40. [CrossRef]

71. Arthur, F.H. Effect of temperature on residual toxicity of cyfluthrin wettable powder. J. Econ. Entomol. 1999, 92, 695-699. [CrossRef]

72. Arthur, F.H.; Yue, B.; E Wilde, G. Susceptibility of stored-product beetles on wheat and maize treated with thiamethoxam: Effects of concentration, exposure interval, and temperature. J. Stored Prod. Res. 2004, 40, 527-546. [CrossRef]

73. Fadamiro, H.Y.; Wyatt, T.D. Flight initiation by Prostephanus truncatus in relation to time of day, temperature, relative humidity and starvation. Entomol. Exp. Appl. 1995, 75, 273-277. [CrossRef] 